\title{
Dietary intakes of phytate and its meal distribution pattern amongst staff and students in an institution of higher education
}

\author{
BY A. WISE, G. M. LOCKIE AND J. LIDDELL \\ School of Nutritional Science, Robert Gordon's Institute of Technology, Queen's Road, \\ Aberdeen $A B 92 P G$
}

(Received 10 November 1986 - Accepted 28 May 1987)

\begin{abstract}
1. Seventy-six students and staff at Robert Gordon's Institute of Technology weighed all items of food consumed for 1 week.

2. Mean phytate-phosphorus intakes ranged from $141 \mathrm{mg}$ for female students to $237 \mathrm{mg}$ for male students. Breakfast was proportionally a more important contributor to daily phytate intakes than to calcium, zinc, and energy intakes. Cereals were the most important contributors to the phytate at breakfast, whilst wholemeal and brown bread were more important at lunch and the evening meal.

3. The phytate: $\mathrm{Zn}$ molar ratio was distributed amongst meals similarly to the more complex ratio, $(\mathrm{Ca} \times$ phytate $):(\mathrm{Zn} \times$ energy) $(\mathrm{CP}: \mathrm{ZE})$; both ratios have been suggested as useful predictors of $\mathrm{Zn}$ availability. CP:ZE ranged more widely when calculated for meals than for days, and therefore some meals could be associated with poor $\mathrm{Zn}$ availability whilst others could compensate with higher availability. Subjects with the highest values for CP:ZE were mostly amongst the group of nutrition students.
\end{abstract}

Phytate (inositol hexaphosphate) intakes vary considerably from very low levels in Sweden (Torelm \& Bruce, 1982) to relatively high levels in countries where unrefined cereals form a large part of the diet (Walker, 1951). There is little information available on the intakes of phytate in Britain and no studies of individual diets and distribution of phytate between meals. The total daily phytate intake may be insufficient information on which to predict its effects on mineral availability. The binding of metal ions to phytate depends on their relative concentrations in each meal, and in digesta passing through the small intestine. It is therefore theoretically possible for a large proportion of the phytate to be ingested at one meal but with only a small proportion of the zinc, or they could be combined together in one meal. Furthermore, calcium is able to potentiate the effects of phytate by forming calcium phytate to which trace quantities of $\mathrm{Zn}$ are bound (Wise, 1983). Therefore the concentration of $\mathrm{Ca}$ in each meal containing phytate and $\mathrm{Zn}$ is likely to be another important variable. Protein is also able to form complexes with phytate and metals (DeRham \& Jost, 1979). It is also possible that peptide-phytate complexes could form during protein hydrolysis (Cheryan, 1980). Certain amino acids are able to desorb some of the $\mathrm{Zn}$ bound to a calcium-phytate precipitate in vitro (Wise, 1983). Dietary fibre may also bind to metal ions, and there has been some controversy about the relative contributions of phytate and fibre to the reduction of metal availability (Davies, 1982).

Several authors have tried to take account of some of these factors by deriving ratios that partially predict the effect of phytate on $\mathrm{Zn}$ availability. Results in animals have suggested that phytate: $\mathrm{Zn}$ molar ratios above 10 may have deleterious effects, including low hair and plasma $\mathrm{Zn}$ concentrations (Davies \& Olpin, 1979; Oberleas \& Harland, 1981). Davies et al. (1985) have suggested that the ratio is more satisfactory when multiplied by the $\mathrm{Ca}$ concentration of the diet expressed in $\mathrm{mmol} / \mathrm{kg}$. Since human diets are not dry like those of experimental animals, Davies \& Mills (1987) have suggested taking account of varying energy densities by calculating a more complex ratio $((\mathrm{Ca}(\mathrm{mmol}) \times$ phytate $(\mathrm{mmol})):(\mathrm{Zn}$ $(\mathrm{mmol}) \times$ energy $(\mathrm{MJ}$ or $\mathrm{Mcal})$ ); $\mathrm{CP}: \mathrm{ZE})$. They have shown from a retrospective analysis of the literature (Reinhold et al. 1973; Sandberg et al. 1982; Cossack \& Prasad, 1983; 
Turnlund et al. 1984; Navert et al. 1985) that $100 \mathrm{mmol} / \mathrm{Mcal}$ may be a critical value, above which negative $\mathrm{Zn}$ balance may be found to occur. The present paper reports the results of a weighed dietary study of the diets of seventy-six people, the amounts of phytate and the relevant predictive ratios calculated on a per day and per meal basis.

\section{METHODS}

The survey included twenty-one female second-year students of Nutrition and Dietetics (subsequently called nutrition students) who undertake this assignment as part of their normal curriculum during January and February. Other students were systematically selected from the student body so that all years and courses were proportionally represented. The response rate of females was $65 \%$ and males $36 \%$, and average ages were 20 (SD $1 \cdot 5, n 25$ ) and 21 (SD 3.3, n 13) years respectively. Full-time staff were also systematically selected, including both academic and non-academic; the response rates and average ages were $73 \%$ and $42(\mathrm{SD} 13, n 8)$ years for females and $69 \%$ and $38(\mathrm{SD} 15, n 9)$ years for males.

The subjects recorded their food intake by the weighed inventory method (Marr, 1965), using Wedo Digital Letter Scales and Salter Dietary Scales Model 512. Analytical values for phytate-phosphorus were taken from Paul \& Southgate (1978), which contains a table of percentage total $\mathbf{P}$ as phytate in various foods analysed several decades ago. Many analyses for specific foods, especially breakfast cereals, have been estimated on the basis of similarity. For all bran-based cereals, the proportion of phytate- $\mathrm{P}$ to total $\mathrm{P}$ was assumed to be similar to All-bran ${ }^{\circledR}$ (Kelloggs), wholemeal bread to $92 \%$ extraction bread, and rolls to bread. All recipes published by Paul \& Southgate (1978) and Wiles et al. (1980) were used to calculate the phytate contents of complete dishes. All biscuits for which no recipe or analysis was available were assumed to be the same as the home-made biscuits for which a recipe has been published (Paul \& Southgate, 1978). The number of foods for which $\mathrm{Zn}$ analyses were unavailable was identified and the energy content calculated as a proportion of the total.

Total daily intakes of phytate- $\mathrm{P}, \mathrm{Ca}, \mathrm{Zn}$, protein, dietary fibre and energy were calculated for each group separately and subjected to the Kruskal-Wallis one-way analysis of variance test. The proportion of daily intake at each meal was calculated for each group and for the seventy-six subjects as a whole.

The total amounts of each nutrient and energy were calculated for the six meals separately ( $n$ 456). These values were subjected to correlation analysis. The mean proportion of total daily phytate contributed by each food was calculated for each group and meal type.

The molar ratio, phytate: $\mathrm{Zn}$ and the more complex ratio, $\mathrm{CP}: \mathrm{ZE}$, have been calculated. The 456 meals were arranged in hierarchical order for each ratio and divided into eleven subgroups of incremental ratios; this calculation was repeated separately for the breakfasts, lunches, evening meals and the three snacks combined. The same ratio was calculated on the basis of the total daily amounts of each component for each person. The frequency distributions obtained in the subgroups calculated on a per meal and per day basis were compared using the chi-squared test for homogenicity. The mean amounts of each nutrient were calculated for each ratio subgroup and the numbers of people falling into each category contributing to the subgroup were counted.

\section{RESULTS}

There were no significant differences between the groups of subjects in the mean intakes of phytate (Table 1). Distribution of nutrients among the meals differed little between groups 


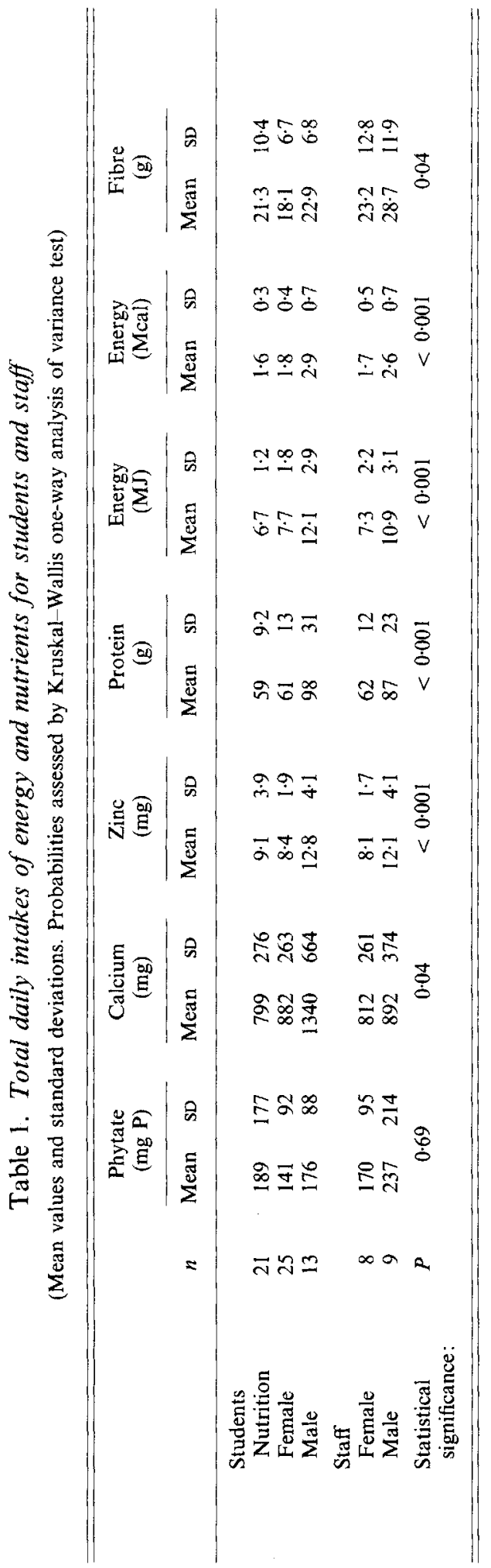




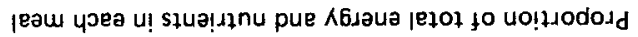

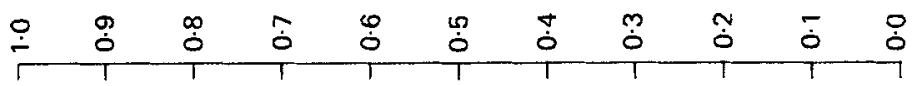

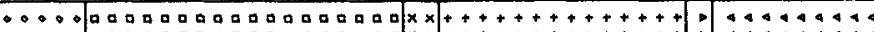
$\because \because 80$ a

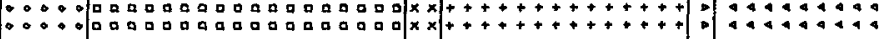

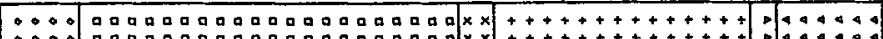

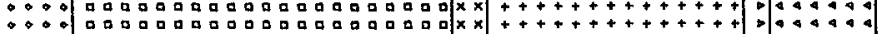

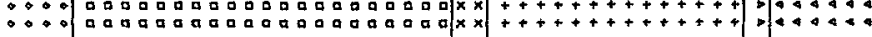

$\stackrel{90}{=}$

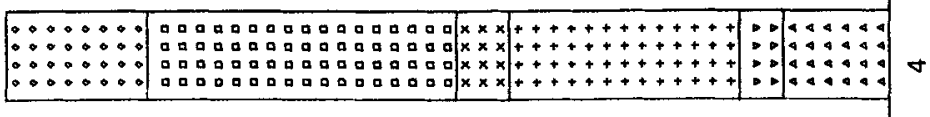

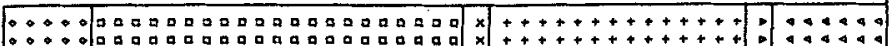

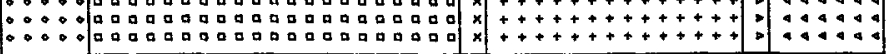

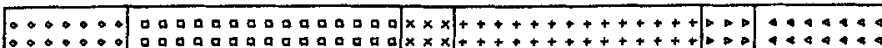

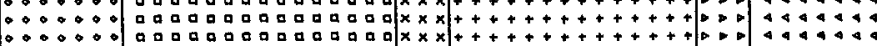

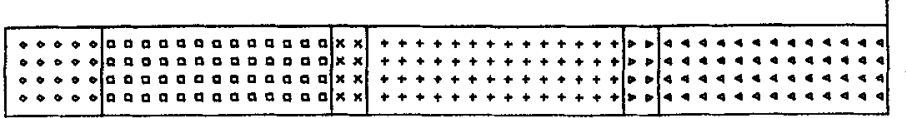

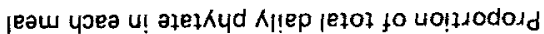

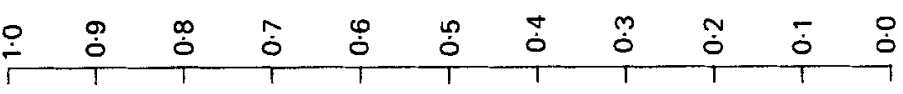

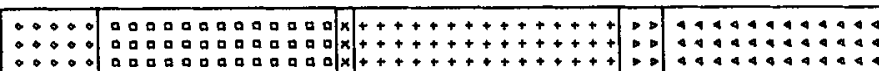

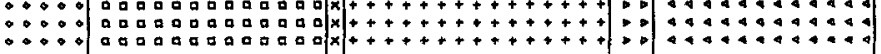

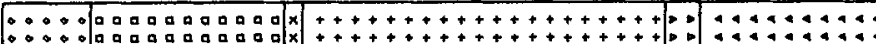
$\because \because \because 0$ a $\because \therefore:$ a ga
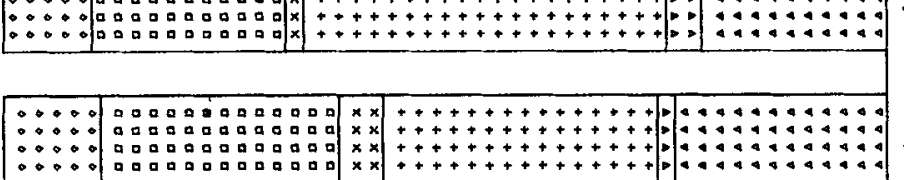

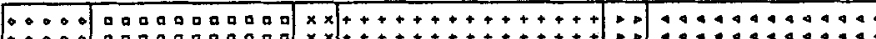
$\because \because 0$ a $\because \because: 0$ a

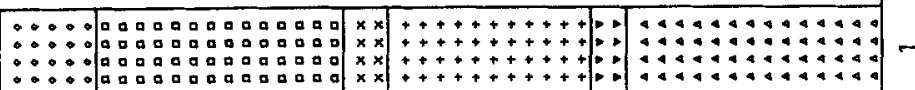
in

矛 $\times$

窇

$N$ $+$

总

$D^{5}$

営

i

造

ব)

$\ddot{\vec{x}}$

है

듈 톤

EN

焉

웡

ज

吾 


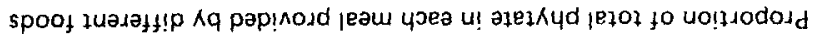

\begin{tabular}{|c|c|c|c|c|c|c|c|c|c|}
\hline \multirow[t]{2}{*}{0} & $\dot{0}$ & $\stackrel{\infty}{\dot{0}}$ & $\hat{0}$ & $\stackrel{\varphi}{0}$ & $\ddot{0}$ & $\dot{0}$ & $\ddot{\dot{0}}$ & $\stackrel{y}{0}$ & $\dot{0}$ \\
\hline & $T$ & $T$ & $T$ & $T$ & $T$ & $T$ & $T$ & $T$ & 7 \\
\hline
\end{tabular}

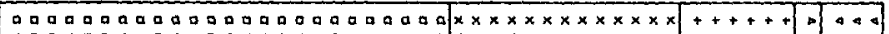

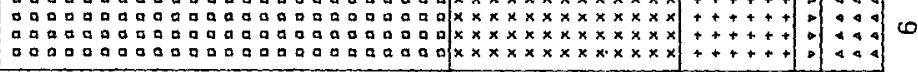

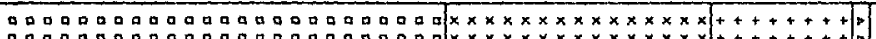

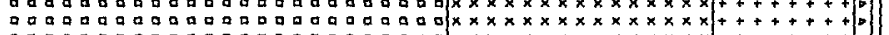

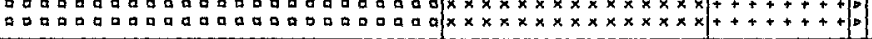

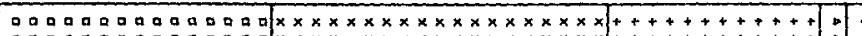
0 a

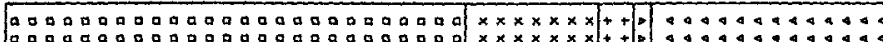
a da

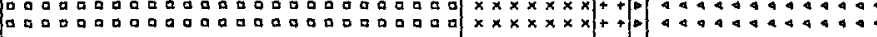

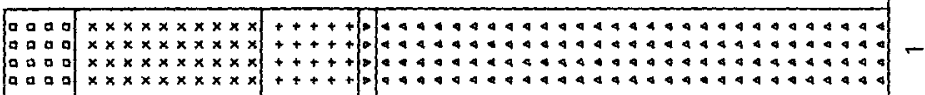

spooł luasałt!p Kq pap!nosd alełkyd Al!ep jęOł fo uo!juodosd

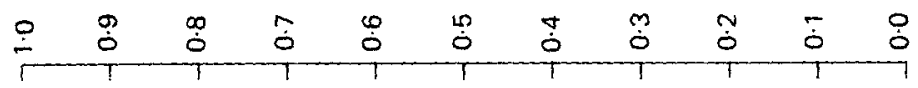

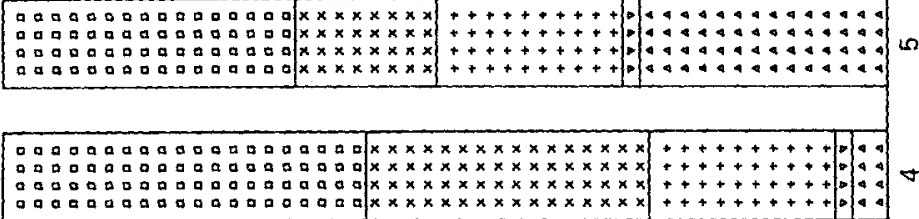


Table 2. Correlation coefficients between dietary components at meals of male and female students and staff

(Partial correlation coefficients allowing for correlations with energy are given in parentheses; statistical significance was attained at the following coefficients : $0.09 P<0.05,0.15 P<0.01,0.19 P<0.001$ )

\begin{tabular}{|c|c|c|c|c|c|}
\hline & Phytate & Calcium & Zinc & Protein & Fibre \\
\hline Energy & 0.36 & 0.80 & 0.80 & 0.92 & 0.71 \\
\hline $\mathrm{Ca}$ & $\begin{array}{c}0.34 \\
(0.01)\end{array}$ & - & - & - & - \\
\hline $\mathrm{Zn}$ & $\begin{array}{c}0.43 \\
(0.25)\end{array}$ & $\begin{array}{c}0.64 \\
(0.00)\end{array}$ & - & - & - \\
\hline Protein & $\begin{array}{c}0.37 \\
(0.11)\end{array}$ & $\begin{array}{c}0.78 \\
(0.19)\end{array}$ & $\begin{array}{c}0.89 \\
(0.65)\end{array}$ & - & - \\
\hline Fibre & $\begin{array}{c}0.69 \\
(0.66)\end{array}$ & $\begin{array}{c}0.59 \\
(0.05)\end{array}$ & $\begin{array}{c}0.69 \\
(0.29)\end{array}$ & $\begin{array}{c}0.73 \\
(0 \cdot 28)\end{array}$ & - \\
\hline
\end{tabular}

Table 3. Comparison of two phytate:zinc molar ratios for 456 meals eaten by male and female students and staff

(The phytate : $\mathrm{Zn}$ molar ratio and (calcium (mmol) $\times$ phytate (mmol)):( $\mathrm{Zn}(\mathrm{mmol}) \times$ energy (MJ or Mcal)) (CP:ZE) for each meal have been ranked and the number of meals falling into incremental subgroups expressed as percentages of the total number; for $C P: Z E$ the average phytate: $Z n$ of the meals falling within each subgroup was also calculated for comparison. CP:ZE was also calculated for the total mean daily intakes for comparison)

\begin{tabular}{|c|c|c|c|c|c|c|c|c|c|}
\hline \multicolumn{3}{|c|}{ Phytate: $\mathrm{Zn}$} & \multicolumn{7}{|c|}{$C P: Z E$} \\
\hline \multirow[b]{2}{*}{ Ranges } & \multirow[b]{2}{*}{$n$} & \multirow[b]{2}{*}{$\%$} & \multirow[b]{2}{*}{$\mathrm{mmol} / \mathrm{Mcal}$} & \multirow[b]{2}{*}{$\mathrm{mmol} / \mathrm{MJ}$} & \multicolumn{3}{|c|}{ Meals } & \multicolumn{2}{|c|}{ Days } \\
\hline & & & & & $n$ & $\%$ & $P: Z$ & $n$ & $\%$ \\
\hline $0-2$ & 105 & $23 \cdot 0$ & $0-20$ & $0-4.8$ & 100 & $22 \cdot 0$ & 0.9 & 3 & 3.9 \\
\hline $2-4$ & 77 & 17.0 & $20-40$ & $4 \cdot 8-9 \cdot 6$ & 77 & 17.0 & 3.9 & 16 & $21 \cdot 0$ \\
\hline $4-6$ & 68 & 15.0 & $40-60$ & $9 \cdot 6-14$ & 59 & $13 \cdot 0$ & $5 \cdot 4$ & 10 & 13.0 \\
\hline $6-8$ & 55 & 12.0 & $60-80$ & $14-19$ & 46 & 100 & 7.6 & 15 & $20 \cdot 0$ \\
\hline $8-10$ & 36 & 7.9 & $80-100$ & $19-24$ & 42 & 9.2 & 8.1 & 15 & 20.0 \\
\hline $10-12$ & 23 & 5.0 & $100-120$ & $24-29$ & 17 & $3 \cdot 7$ & 9.7 & 7 & 9.2 \\
\hline $12-14$ & 20 & $4 \cdot 4$ & $120-140$ & $29-33$ & 13 & $2 \cdot 9$ & 8.9 & 1 & $1 \cdot 3$ \\
\hline 1416 & 12 & $2 \cdot 6$ & $140-160$ & $33-38$ & 21 & 4.6 & 14.0 & 2 & $2 \cdot 6$ \\
\hline $16-18$ & 8 & 1.7 & $160-180$ & $38-43$ & 11 & $2 \cdot 4$ & $15 \cdot 0$ & 2 & $2 \cdot 6$ \\
\hline $18-20$ & 16 & $3 \cdot 5$ & $180-200$ & $43-48$ & 8 & 1.7 & 13.0 & 1 & $1 \cdot 3$ \\
\hline$>20$ & 36 & $8 \cdot 1$ & $>200$ & $>48$ & 62 & 13.0 & $21 \cdot 0$ & 4 & $5 \cdot 2$ \\
\hline
\end{tabular}

and is only shown for phytate in Fig. 1. The distribution of each dietary component for the seventy-six subjects is shown in Fig. 2. The number of foods for which $\mathrm{Zn}$ analysis had been unavailable was $11 \%$ of the total, and these accounted for $15 \%$ of the total energy. The proportion of phytate contributed by different foods was similar for each group, but the female staff apparently consumed little phytate in breakfast cereals, which were generally about as important as contributors to the dietary phytate as wholemeal bread, followed by brown bread (Fig. 3). Cereals were the most important contributors to the phytate at breakfast, whilst wholemeal and brown bread were more important at lunch and the evening meal (Fig. 4). Many other foods combined to supply a large proportion of the phytate at snacks and the evening meal.

When the total composition of each meal (i.e. 456 meals) was subjected to correlation 
Table 4. (Calcium (mmol) $\times$ phytate $(\mathrm{mmol})$ :(zinc $(\mathrm{mmol}) \times$ energy $(\mathrm{MJ}$ or $\mathrm{Mcal}))$ $(C P: Z E)$ ratios at different meals for male and female students and staff

(Distribution as percentage of total for meals)

\begin{tabular}{cccccc}
\hline mmol/Mcal & mmol/MJ & Breakfast & Lunch & $\begin{array}{c}\text { Evening } \\
\text { meal }\end{array}$ & $\begin{array}{c}\text { Snacks } \\
\text { combined }\end{array}$ \\
\hline $0-20$ & $0-4 \cdot 8$ & $10 \cdot 5$ & $11 \cdot 8$ & $28 \cdot 9$ & $5 \cdot 3$ \\
$20-40$ & $4 \cdot 8-9 \cdot 6$ & $6 \cdot 6$ & $22 \cdot 4$ & $32 \cdot 9$ & $18 \cdot 4$ \\
$40-60$ & $9 \cdot 6-14$ & $7 \cdot 9$ & $14 \cdot 5$ & $17 \cdot 1$ & $18 \cdot 4$ \\
$60-80$ & $14-19$ & $9 \cdot 2$ & $9 \cdot 2$ & $7 \cdot 9$ & $15 \cdot 8$ \\
$80-100$ & $19-24$ & $5 \cdot 3$ & $9 \cdot 2$ & $6 \cdot 6$ & $10 \cdot 5$ \\
$100-120$ & $24-29$ & $2 \cdot 6$ & $7 \cdot 9$ & $1 \cdot 3$ & $6 \cdot 6$ \\
$120-140$ & $29-33$ & $3 \cdot 9$ & $2 \cdot 6$ & $5 \cdot 3$ & $9 \cdot 2$ \\
$140-160$ & $33-38$ & $11 \cdot 9$ & $7 \cdot 9$ & 0 & $6 \cdot 6$ \\
$160-180$ & $38-43$ & $5 \cdot 3$ & $5 \cdot 3$ & 0 & $2 \cdot 6$ \\
$180-200$ & $43-48$ & $3 \cdot 9$ & $1 \cdot 3$ & 0 & $1 \cdot 3$ \\
$>200$ & $>48$ & $32 \cdot 9$ & $7 \cdot 9$ & 0 & $5 \cdot 3$ \\
\hline
\end{tabular}

Table 5. Characteristics of diets with different (calcium $(\mathrm{mmol}) \times$ phytate $(\mathrm{mmol}):(\mathrm{zinc}$ (mmol) $\times$ energy $(M J$ or $M c a l))(C P: Z E)$ ratios for male and female students and staff

(For different ranges of $\mathrm{CP}: \mathrm{ZE}$, the number of nutrition students $(\mathrm{N})$, female students $(\mathrm{F})$, male students (M), female staff (Fs), and male staff (Ms), whose diets exhibited these ratios, and the total (Tot) number are shown. The mean amounts of phytate (mmol), $\mathrm{Zn}(\mu \mathrm{mol}), \mathrm{Ca}(\mathrm{mmol})$, and dietary fibre $(\mathrm{g})$, and the percentage recommended amounts of energy achieved by these people are also shown. The percentage of recommendations (Department of Health and Social Security, 1979) of energy were calculated as a weighted mean depending on the number of people in each range of $\mathrm{CP}: \mathrm{ZE}$ )

\begin{tabular}{ccccccccccccc}
\hline mmol/Mcal & mmol/MJ & N & F & M & Fs & Ms & Tot & Phytate & Zn & Ca & Fibre & Energy \\
\hline $0-20$ & $0-4 \cdot 8$ & 1 & 2 & 0 & 0 & 1 & 3 & $0 \cdot 3$ & 241 & 18 & 16 & 89 \\
$20-40$ & $4 \cdot 8-9 \cdot 6$ & 2 & 6 & 5 & 1 & 2 & 16 & $0 \cdot 5$ & 153 & 20 & 16 & 95 \\
$40-60$ & $9 \cdot 6-14$ & 2 & 4 & 1 & 0 & 3 & 10 & $0 \cdot 9$ & 175 & 25 & 24 & 104 \\
$60-80$ & $14-19$ & 4 & 3 & 4 & 3 & 1 & 15 & $0 \cdot 8$ & 140 & 25 & 20 & 80 \\
$80-100$ & $19-24$ & 4 & 7 & 2 & 1 & 1 & 15 & $1 \cdot 2$ & 141 & 24 & 21 & 89 \\
$100-120$ & $24-29$ & 2 & 2 & 1 & 2 & 0 & 7 & $0 \cdot 9$ & 114 & 22 & 23 & 70 \\
$120-140$ & $29-33$ & 1 & 0 & 0 & 0 & 0 & 1 & $2 \cdot 8$ & 161 & 13 & 39 & 77 \\
$140-160$ & $33-38$ & 1 & 0 & 0 & 1 & 0 & 2 & $1 \cdot 6$ & 157 & 35 & 31 & 109 \\
$160-180$ & $38-43$ & 2 & 0 & 0 & 0 & 0 & 2 & $1 \cdot 7$ & 138 & 23 & 38 & 77 \\
$180-200$ & $43-48$ & 1 & 0 & 0 & 0 & 0 & 1 & $1 \cdot 4$ & 127 & 23 & 22 & 63 \\
$>200$ & $>48$ & 1 & 2 & 0 & 0 & 1 & 4 & $1 \cdot 9$ & 134 & 24 & 31 & 70 \\
\hline
\end{tabular}

analysis, all components were correlated, one with another (see Table 2), but in most cases these correlations were considerably reduced when their relations to energy were accounted for. Only the partial correlations between phytate and fibre, and $\mathrm{Zn}$ and protein remained relatively high.

Table 3 shows how the phytate: $\mathrm{Zn}$ molar ratio was distributed amongst the 456 meals, with only $25 \%$ having ratios higher than 10 , but as many as $8 \%$ were greater than 20 . The distribution of CP:ZE was similar to that of phytate:Zn (see Table 3). However, when CP:ZE was calculated on the basis of total daily amounts of nutrients, rather than individual meals, the distribution was significantly $(P<0.01)$ different (see Table 3). There were fewer extreme ratios and $74 \%$ were between 20 and $100 \mathrm{mmol} / \mathrm{Mcal}(4 \cdot 8-24 \mathrm{mmol} /$ $\mathrm{MJ}$ ), whereas on the basis of individual meals, only $49 \%$ were in this range.

The distribution of CP: ZE differed amongst the meals (see Table 4). Breakfasts consisted 
of a wide range of ratios, with $33 \%$ greater than $200 \mathrm{mmol} / \mathrm{Mcal}(48 \mathrm{mmol} / \mathrm{MJ})$, while evening meals consisted mainly of lower ratios and none above $140 \mathrm{mmol} / \mathrm{Mcal}$ ( $33 \mathrm{mmol} /$ MJ). Lunches and snacks were intermediate.

The distribution of CP: ZE calculated on the basis of total daily intakes is explored in greater depth in Table 5. No male students, and only one male member of staff, had ratios above $120 \mathrm{mmol} / \mathrm{Mcal}(29 \mathrm{mmol} / \mathrm{MJ}$ ), so most of the people showing higher ratios were females, especially nutrition students.

\section{DISCUSSION}

The analytical method for phytate based on ferric-phytate precipitation has not changed fundamentally since the basic food tables were first published, but it is now known that the method includes various inositol phosphates with less than six phosphate groupings (Anderson, 1963). These are produced during food preparation by the action of phytase (Nayini \& Markakis, 1983) and their metal-binding characteristics (Kaufman \& Kleinberg, 1971) and in vivo actions on $\mathrm{Zn}$ availability (Tao et al. 1986) are not the same as the hexaphosphate. The activity of phytase during food preparation varies from one process to another and depends on the kind of flour employed (Daniels \& Fisher, 1981), so the analyses used in the present study are recognized to be in error and may overestimate the likely metal-binding activity of the phytate-P. Nevertheless, until there is a great improvement in the amount of relevant information available on the inositol phosphate contents of representative British foods, and concurrently more research into their individual metal-binding characteristics, the analyses used in the present study represent the best available information. Although large numbers of foods contributed some phytate to the diets, the majority was present in breakfast cereals and high-extraction-rate breads, so these should receive priority for the most extensive analysis.

Similarly there is, as yet, no simple method of predicting how all the possible factors involved in $\mathrm{Zn}$ availability interact, and even less information is available for other trace metals. The favourable effect of protein on $\mathrm{Zn}$ availability (Sandstrom et al. 1980; Davies, 1982) could partly be due to the formation of complexes with phytate competing with $\mathrm{Ca}$ for the formation of a precipitate of $\mathrm{Ca}$ phytate and also the desorption of soluble amino acid chelates of $\mathrm{Zn}$ from $\mathrm{Ca}$ phytate that has formed (Wise, 1983). In individual meals there was a relatively high partial correlation between $\mathrm{Zn}$ and protein. Since $\mathrm{Zn}$ and phytate showed a low correlation, it follows that there are combinations of lower $\mathrm{Zn}$, and hence protein, with higher phytate concentrations and vice versa. The correlation between $\mathrm{Ca}$ and phytate approximated zero, so meals can be relatively high in phytate with or without high levels of $\mathrm{Ca}$.

There have been various attempts to make predictive equations for $\mathrm{Zn}$ availability taking into account some of the factors mentioned previously. The simple molar ratio, phytate $\mathrm{Zn}$ has been satisfactory in some animal experiments, but the variability of dietary $\mathrm{Ca}$ and its potential effects on phytate binding in the intestine should also be taken into account. This has been attempted by calculating $\mathrm{CP}: \mathrm{ZE}$. In vitro, a high $\mathrm{Ca}$ : phytate ratio results in precipitation and binding of $\mathrm{Zn}$, whilst a low ratio fails to precipitate phytate or bind $\mathrm{Zn}$ (Wise, 1983). Both cases result in a relatively low ( $\mathrm{Ca} \times$ phytate) $: \mathrm{Zn}$ value. In the first case, the phytate concentration is low and hence it may have less effect as a $\mathrm{Zn}$-binding agent compared with the soluble chelating agents, like amino acids. In the second case although the phytate concentration is high, the failure to form a precipitate may allow it to have a negligible effect on $\mathrm{Zn}$ availability (Wise, 1983). At values for $\mathrm{Ca}$ : phytate in between these two extremes, the product of $\mathrm{Ca} \times$ phytate is greater and the presence of a significant amount of a $\mathrm{Ca}$ phytate precipitate containing $\mathrm{Zn}$ is more likely. The utility of the 
$(\mathrm{Ca} \times$ phytate $): \mathrm{Zn}$ value has been demonstrated in animals, and it has been proposed that a similar expression may also be useful for human diets. Davies \& Mills (1987) have argued that, whilst rat diets are generally dry and low in fat, human diets have neither of these properties. The $(\mathrm{Ca} \times$ phytate) $: \mathrm{Zn}$ value for a rat diet may generally be calculated using dietary concentrations in $\mathrm{mol} / \mathrm{kg}$ for each component. For human diets it is more appropriate to express intakes as $\mathrm{mol} / \mathrm{d}$ or $\mathrm{mol} / \mathrm{meal}$, since energy density varies widely, In order to take account of the energy density, it has been proposed that energy/d be included in the ratio, which is therefore expressed on a mol/energy (MJ or Mcal) basis. It is suggested that $\mathrm{Zn}$ availability might be predicted from calculation of this ratio, and empirically it has been found that a ratio over $100 \mathrm{mmol} /$ Mcal provokes negative $\mathrm{Zn}$ balance in several human studies. The present study found that the distribution patterns for phytate:Zn and CP:ZE were similar (see Table 3), but more emphasis has been placed on the latter ratio, since it takes more variables into account. The ratio has been calculated using energy either as Mcal or $\mathrm{MJ}$; the former has been chosen for subgrouping in hierarchical order because the suggested critical value of $100 \mathrm{mmol} / \mathrm{Mcal}$ is more convenient than the equivalent value in MJ.

Phytate is taken with $\mathrm{Ca}$ and $\mathrm{Zn}$ at individual meals during the day, much of which will have left the stomach before the next is taken. This means that the predictive value for $1 \mathrm{~d}$ could be confounded by taking the components unevenly throughout the day. The present study indicates that $\mathrm{CP}: \mathrm{ZE}$ has a greater range when calculated for meals than when calculated for total daily intakes. Theoretically there might be even greater differences between individual meals, because all ratios calculated in the present study were derived from total nutrient analyses for the meals over a $7 \mathrm{~d}$ period. No estimate of intra-individual variation has been attempted, as for example by using analysis of variance, for several reasons in addition to the non-normality of the distributions and heteroscedasity of the data. Unlike metabolic experiments, studies of human behaviour, like the present one, end up with many missing values, not because of lost samples, but because people skipped meals. This is particularly well-known for breakfast, but is even more common for snacks. Since subjects were more likely to skip some types of meal than others, the number of missing meals varies. The ratio for a meal containing no phytate would be zero, but clearly it should not be treated as zero or as a missing value. Second, many meals, especially breakfast and snacks, consist of a single food such as biscuits. In this case there may be a very small amount of phytate, the analysis of which is only approximate. The ratio therefore will depend on the analysis of the other factors that make up the ratio. Additionally, for $11 \%$ of the foods, there was no value in the food tables for $\mathrm{Zn}$, so the calculated ratio for that meal is meaningless. Other meals of the same type, eaten on other days, may be quite substantial, especially at the weekend. Summation of all the meals of each type allows for a reduction in the extent of all these potential errors in the minor meals.

There were differences in the distribution of $\mathrm{CP}: \mathrm{ZE}$ between meals, with breakfast showing the greatest number of high values, because of the high consumption of breakfast cereals and wholemeal bread at this meal by some individuals. Unfortunately the relatively low response rate of male students reduces the probable validity of inter-group comparisons, but it can be generalized that most of the people with high ratios also showed high intakes of dietary fibre, and some showed tendencies towards low-energy intakes compared with those recommended (Department of Health and Social Security, 1979). A fuller analysis of the food habits of these subjects has been published elsewhere (Wise et al. 1987).

It is now recognized that refined diets are lacking in dietary fibre and higher intakes are being suggested (National Advisory Commitee on Nutrition Education, 1983). Since 
phytate was correlated to dietary fibre in the meals analysed in the present study, increased consumption of dietary fibre is likely to increase the intake of phytate. It is therefore of interest to note that subjects with high $C P: Z E$ ratios were mainly females who had high dietary fibre intakes, but that they also tended to have relatively low energy intakes. Further research is needed to show whether subjects with these dietary characteristics have impaired $\mathrm{Zn}$ availability, as suggested by the present study. Any future research on $\mathrm{Zn}$ availability should consider the composition of meals, in addition to the total daily intakes.

This project has been partly funded by the Scottish Health Education Group.

\section{REFERENCES}

Anderson, G. (1963). Journal of the Science of Food and Agriculture 14, 352-359.

Cheryan, M. (1980). CRC Critical Reviews in Food Science and Nutrition 13, 297-335.

Cossack, Z. T. \& Prasad, A. S. (1983). Nutrition Research 3, 23-32.

Daniels, D. G. H. \& Fisher, N. (1981). British Journal of Nutrition 46, 1-6.

Davies, N. T. (1982). In Dietary Fibre in Health and Disease, pp. 105-106 [G. V. Vahouny and D. Kritchevsky, editors]. New York: Plenum Press.

Davies, N. T., Carswell, A. J. P. \& Mills, C. F. (1985). In Trace Elements in Man and Animals (TEMA-5), pp. 456-458 [C. F. Mills, I. Bremner and J. K. Chesters, editors]. Slough: Commonwealth Agricultural Bureaux.

Davies, N. T. \& Mills, C. F. (1987). Human Nutrition: Applied Nutrition (In the Press).

Davies, N. T. \& Olpin, S. E. (1979). British Journal of Nutrition 34, $243-258$.

Department of Health and Social Security (1979). Report on Health and Social Subjects no. 15. London: H.M. Stationery Office.

DeRham, O. \& Jost, T. (1979). Journal of Food Science 44, 596-600.

Kaufman, H. W. \& Kleinberg, I. (1971). Archives of Oral Biology 16, 445-460.

Marr, J. W. (1965). Nutrition 19, 18-24.

National Advisory Committee on Nutrition Education (1983). A Discussion Paper on Proposals for Nutritional Guidelines for Health Education in Britain. London: Health Education Council.

Navert, B., Sandstrom, B. \& Cederblad, A. (1985). British Journal of Nutrition 53, 47-53.

Nayini, N. R. \& Markakis, P. (1983). Journal of Food Science 48, 262-263.

Oberleas, D. \& Harland, B. F. (1981). Journal of the American Dietetic Association 79, 433-436.

Paul, A. A. \& Southgate, D. A. T. (1978). McCance and Widdowson's The Composition of Foods. London: H.M. Stationery Office.

Reinhold, J. G., Nasr, K., Lahimgarzadeh, A. \& Hedayati, H. (1973). Lancet i, 283-288.

Sandberg, A., Hasselblad, C., Hasselblad, K. \& Leif, H. (1982). British Journal of Nutrition 48, 185-192.

Sandstrom, B., Arvidsson, B., Cederblad, A. \& Bjorn-Rasmussen, E. (1980). American Journal of Clinical Nutrition 33, 739-745.

Tao, S. H., Fox, M. R. S., Phillippy, B. Q., Fry, B. E., Johnson, M. L. \& Johnston, M. R. (1986). Federation Proceedings 45, 819 .

Torelm, A. I. \& Bruce, A. (1982). Var Foda 34, 79-96.

Turnlund, J. R., King, J. C., Keyies, W. R., Gong, R. \& Michel, M. C. (1984). American Journal of Clinical Nutrition 40, 1071-1077.

Walker, A. R. P. (1951). Lancet ii, 244-248.

Wiles, S. J., Nettleton, P. A., Black, A. E. \& Paul, A. A. (1980). Journal of Human Nutrition 34, $189-223$.

Wise, A. (1983). Nutrition Abstracts and Reviews 53A, 791-806.

Wise, A., Liddell, J. A. \& Lockie, G. M. (1987). Human Nutrition: Applied Nutrition 41 A, 118-134. 